\title{
BENTUK GERAK TARI SRIMPI KADANG PREMATI \\ SEBAGAI MATERI PEMBELAJARAN PADA MATA KULIAH SEJARAH DAN ANALISIS TARI \\ DI UNIVERSITAS PGRI PALEMBANG
}

\author{
Oleh: \\ Rully Rochayati \\ (Dosen FKIP Prodi Pendidikan Sendratasik Universitas PGRI Palembang)
}

\begin{abstract}
Abstrak
Sejarah dan Aanalisis Tari, adalah salah satu mata kuliah yang ada di semester 6 (enam) di Program Studi Pendidikan Sendratasik Jurusan Pendidikan Kesenian Fakultas Keguruan dan IImu Pendidikan Universitas PGRI Palembang. Mata kuliah teori yang berisi tentang pengetahuan sejarah dan analisisnya. Salah satu pembahasannya tentang analisis tekstual. Salah satu yang akan dibahas adalah analisis bentuk gerak dengan materi tari Srimpi Kadang Premati. Pemilihan tari Srimpi Kadang Premati sebagai materi ajar karena dalam konsep bentuk gerak, tari Srimpi Kadang Premati memiliki kompleksitas yang dapat dikaji, dianalisa, dan dapat juga dipelajari. Metode penelitian yang digunakan adalah deskriptif kualitatif dengan teknik pengumpulan data melalui wawancara, observasi langsung, dan kajian dokumen. Sedangkan Validitas data guna memperoleh hasil data yang maksimal terjabarkan dalam proses pemaparan hasil penelitian, pembahasan dan penarikan simpulan. Dengan adanya validitas data triangulasi yang digunakan: triangulasi data, triangulasi metode. Hasil penelitian yang dicapai adalah adanya relevansi materi dengan mata kuliah yang ada. Pemilihan materi tersebut dengan berbagai pertimbangan yang matang sehingga dengan begitu semua proses pembelajaran berlangsung dengan baik dan materi pembelajaran dapat diterima serta dipahami oleh mahasiswa.
\end{abstract}

\section{Kata Kunci: Bentuk Gerak, Tari Srimpi kadang Premati, Materi Pembelajaran}

\section{A. PENDAHULUAN}

Sejarah dan Analisis Tari adalah salah satu mata kuliah yang proses pembelajarannya dilaksanakan pada setiap semester 6 (enam/genap) pada Program Studi Pendidikan Sendratasik Jurusan Pendidikan Kesenian Fakultas Keguruan dan IImu Pendidikan Universitas PGRI Palembang. Mata Kuliah Sejarah dan Analisis Tari merupakan mata kuliah teori yang berisi tentang pengetahuan sejarah tari dan analisisnya. Mata kuliah Sejarah dan Analisis Tari memberikan bagian-bagian penting dalam menganalisa seni tari dari sejarah, fungsi, bentuk, hingga menelaah seni tari yang berhubungan dengan lingkungan masyarakatnya. Berbagai hal yang dipelajari dari mata kuliah ini termasuk menganalisa tari dalam ruang lingkup tekstual dan konstekstual.

Suatu mata kuliah yang kurang menarik dan menjemukan karena tidak saja mempelajari bagaimana sejarah tari itu terbentuk tetapi juga mempelajari bagaimana tari itu sebagai objek dapat dianalisa, dikaji dari aspek-aspek terkait. Untuk itu seorang 
mahasiswa yang mencoba mempelajari Sejarah dan Analisis Tari maka harus membekali dirinya dengan teori-teori yang berkaitan dengan sejarah tari, dan teori-teori yang biasanya digunakan untuk menganalisisnya. Sebagai contoh pada pembahasan fungsi dan bentuk tari maka mahasiswa wajib memahami dan mengerti fungsi dan bentuk tari yang berkembang di suatu masyarakatnya dan bagaimana cara menganalisanya.

Cakupan materi yang begitu luas tentu tidak dapat dengan mudah untuk dipahami, mengingat keterbatasan waktu belajar. Untuk itu supaya mahasiswa dapat memahaminya maka diperlukan contohcontoh yang konkret dan jelas dari setiap pembahasan. Misalnya pembahasan tentang analisis teks dan konteks yang hanya dipelajari 6 jam pertemuan (3 kali tatap muka). Banyak materi yang seharusnya dipaparkan namun karena keterbatasan waktu pada setiap pertemuannya maka hanya diambil materi-materi teks dan konteks yang biasa digunakan dalam menganalisa sebuah tari. Dengan adanya contoh-contoh yang konkret maka mahasiswa akan lebih memahami tentang teori yang disampaikan oleh pengajar.

Terkait dengan materi pembelajaran, yang akan dijadikan contoh dalam tulisan ini adalah tari Srimpi Kadang Premati. Tari
Srimpi yang diciptakan pada tahun 2004 sebagai salah satu pemenuhan tugas ahkir tingkat pascasarjana di Insititut Seni Indonesia Yogyakarta ini mencoba dijadikan materi pembelajaran untuk mata kuliah Sejarah dan Analisis Tari. Pemilihan materi tari ini didasarkan atas pertimbangan bahwa karya tari ini dapat dikaji dari berbagai sudut pandang dan berbagai kajian teori, salah satunya adalah kajian teks yaitu bentuk gerak.

Kajian teks dalam teori Y.Sumandiyo Hadi ( 2007:23) dapat diartikan bahwa fenomena tari dipandang sebagai bentuk secara fisik (teks) yang relatif berdiri sendiri, yang dapat dibaca, ditelaah atau dianalisis secara tekstual atau "men-teks" sesuai dengan konsep pemahamannya. Artinya bahwa tari sebagai objek dapat dikaji dan dianalisa secara utuh atau secara keseluruhan dan bisa juga dikaji secara perbagian. Dapat dipahami bahwa tari yang dikaji secara utuh maka elemen-elemen apa saja yang terkait dapat dituliskan dan dijabarkan dalam satu kesatuan. Sedangkan tarian yang dikaji perbagian dapat dipahami bahwa aspek-aspek tari tersebut dipilahpilahkan kemudian dilakukan penganalisaan. Sebagai contoh bentuk gerak tari Srimpi Kadang Premati adalah salah satu aspek yang ada dalam kajian tekstual yang dapat dianalisis secara terpisah. 
Analisis bentuk gerak adalah menganalisis proses mewujudkan atau mengembangkan suatu bentuk dengan pertimbangan prinsip-prinsip bentuk menjadi sebuah gerak tari. Dipertegas pula dalam konsep analisis bentuk gerak nantinya akan dibahas poin-poin penting tentang prinsipprinsip bentuk yang dianalisa antara lain kesatuan, variasi, repetisi atau ulangan, transisi atau perpindahan, rangkaian, perbandingan, dan klimaks (Hadi. 2007:25). Sesuai teori tersebut maka tari Srimpi Kadang Premati dianalisis bentuk geraknya dari prinsip-prinsip bentuk yaitu kesatuan, variasi, repetisi atau ulangan, transisi atau perpindahan, rangkaian, perbandingan, dan klimaks. Ketika sudah dilakukan penganalisaan, maka materi tersebut yang akan disampaikan kepada mahasiswa sebagai bahan atau materi pembelajaran.

Pemilihan materi bentuk gerak ini tentunya dengan berbagai pertimbanganpertimbangan antara lain mahasiswa dapat memahami lebih lanjut dan mendalam bahwa ketika mengkaji suatu karya tari perlu mengetahui terlebih dahulu teori yang akan digunakan. Selain itu analisis bentuk gerak meletakkan suatu karya tari dapat diteliti secara menyeluruh dari aspek gerak. Mahasiswa yang nantinya akan mengikuti mata kuliah lanjutan yaitu mata kuliah Koreografi maka dapat mencoba menerapkannya pada karya-karya yang dibuatnya.

\section{B. METODE PENELITIAN}

Metode penelitian yang digunakan adalah deskriptif kualitatif, dengan sumber data dokumen dan informan. Tempat penelitian Program Studi Pendidikan Sendratasik, Jurusan Pendidikan Kesenian, Fakultas Keguruan dan Ilmu Pendidikan, Universitas PGRI Palembang dalam Mata Kuliah Sejarah dan Analisis Tari. Teknik pengumpulan data melalui wawancara, observasi langsung dan kajian dokumen. Sedangkan Validitas data guna memperoleh hasil data yang maksimal terjabarkan dalam proses pemaparan hasil penelitian, pembahasan dan penarikan simpulan. Dengan adanya validitas data triangulasi yang digunakan: triangulasi data, triangulasi metode.

\section{PEMBAHASAN DAN HASIL PENELITIAN}

\section{Tari Srimpi Kadang Premati}

Tari Srimpi Kadang Premati adalah salah satu karya tari yang diciptakan pada tahun 2004 sebagai pemenuhan tugas ahkir tingkat pascasarjana di Insititut Seni Indonesia Yogyakarta. Karya tari yang dipertunjukkan pada hari Kamis, 17 Juni 
2004 bertempat di Rumah Budaya Tembi, jalan Parangtritis K.M 8.4 Sewon Bnatul Yogyakarta ini berdurasi kurang lebih 60 menit.

Karya tari yang yang berisi tentang perjalanan keempat saudara manusia yang terwujud dalam nafsu yaitu amarah, aluamah, supiyah dan mutmai'nah. Tari yang divisualkan oleh sembilan penari putri yang terbagi atas lima penari inti atau penari srimpi, dan empat penari pada bagian introduksi atau pembuka. Karya tari ini mengacu pada konsep srimpi yang diolah dan dikembangkan berdasarkan pola pikir dan kemampuan penata tari. Perwujudannya mengarah pada gerak-gerak yang simbolik dengan tipe tari dramatik.

Srimpi Kadang Premati memiliki arti, tarian yang dilakukan oleh lima orang penari puteri yang menceritakan tentang saudara terbaik dan pilihan yang telah ditentukan oleh Tuhan untuk menyertai kehidupan manusia dari dikandung, lahir, menjalani kehidupan hingga kematian. Saudara itu juga yang nantinya akan menyucikan keadaan manusia ketika telah mati. Pijakan dasar dari karya tari ini adalah tari Srimpi. Srimpi merupakan simbol dari keseimbangan dunia yang terungkap melalui timur-barat, siang-malam, panas-dingin, baik-jahat, dan sebagainya. Keseimbangan juga terungkap lewat gerak, pola lantai, alur, dan dari keseluruhan karya tari ini didalamnya termuat keseimbangan gerak mengarah ke gerak dengan desain asimetris, sedangkan pola lantai mengarah ke desain yang simetris.

\section{Gerak Tari Srimpi Kadang Premati} Orientasi gerak dasar yang dipakai dalam karya tari Srimpi Kadang Premati ini adalah ngenceng. Ngenceng merupakan ragam dasar dari tari putri gaya Yogyakarta yang memiliki karakteristik tenang, pelan dengan poros atau pusat kekuatan pada cethik. Ngenceng secara keseluruhan terdiri dari delapan hitungan dengan gerak berkualitas mengalun, tenang, bertumpu pada oyogan dan ngleyek. Ngenceng yang dalam tari gaya Yogyakarta telah mempunyai beragam variasi dan pengembangan dimanfaatkan sebagai bahan acuan untuk mengembangkannya ke motif gerak selanjutnya.

Ngenceng dalam gerak diuraikan sebagai berikut, ragam gerak tangan kiri ditekuk ke depan dengan posisi tangan ngruji, tangan kanan memegang udhet dengan posisi nyempurit, badan digerakkan ke kiri dan ke kanan, (Sudarsono, et.al.1978: 125). Ngenceng dalam arti kata adalah lurus, ngencengi dapat berarti meregangkan, membuat tegang, mengeras, mengikat eraterat, (S. Prawiroatmodjo.1980:440). Ngenceng sebagai motif memiliki kekuatan pada cethik sebagai poros gerak yang 
dihasilkan berdasarkan pola waktu adalah kontinyu-berurutan, dengan pola tenaga yang digunakan adalah fleksibel dengan fokus garis atau desain gerak yang menciptakan garis imajiner seperti pada tekuk lengkung atau nglawe. Secara sederhana pengembangan motif ngenceng dilakukan berdasarkan pengulangan, variasi pola ruang, waktu dan tenaga. Pengembangan pola ruang dapat diterjemahkan dalam berbagai bentuk seperti aksi atau penekanan pada bagian-bagian tertentu dari gerak ngenceng, arah hadap, level, desain lantai. Pengolahan tenaga diwujudkan dalam bentuk usaha atau bobot yang biasanya dihubungkan dengan kualitas gerak atau energi yang mengalir pada tubuh atau bagian-bagian lain dari tubuh yang tidak biasa digerakan secara maksimal dan peralihan tenaga yang muncul berat dan ringan. Pengolahan pola waktu terjalin melalui tempo, ritme yang bervariasi.

Bentuk Gerak Tari Srimpi Kadang Premati

Konsep kebentukan ini tari Srimpi Kadang Premati dilihat, dipahami, dan dianalisa dengan sudut pandang secara keseluruhan dari karya tersebut. "Gerak" adalah dasar ekspresi, oleh sebab itu gerak yang ditemui sebagai ekspresi dari semua pengalaman emosional yang diekspresikan lewat medium yang tidak rasional, yakni gerakan tubuh atau (ebahing sadaya sarandhuning badhan) gerakan seluruh tubuh, Bentuk gerak dalam karya tari Srimpi Kadang Premati merupakan pembahasan tentang karya tari yang secara keseluruhan dibahas dalam konsep-konsep analisis teks yang meliputi prinsip-prinsip bentuk yang dianalisa antara lain kesatuan, variasi, repetisi atau ulangan, transisi atau perpindahan, rangkaian, perbandingan, dan klimaks (Hadi.2007: 25).

\section{a) Kesatuan}

Prinsip pertama adalah kesatuan atau unity yaitu prinsip yang sangat penting dalam bentuk gerak atau koreografi. Kesatuan mengandung pengertian satu yang utuh. Kesatuan yang meliputi aspek gerak, ruang dan waktu yang hadir didalam tari adalah keutuhan yang siap dihayati dan dimengerti (Hadi. 2007:25-26). Prinsip kesatuan dalam karya tari Srimpi Kadang Premati dapat dipahami dari aspek gerak, ruang dan waktu. Apabila dijabarkan atau diuraikan maka bentuk karya tari Srimpi Kadang Prematisebagai berikut:

\section{b) Aspek Gerak}

Aspek gerak tari yang digunakan dalam karya tari Srimpi Kadang Premati adalah gerak ngenceng yang merupakan ragam gerak dasar dari tari puteri gaya Yogyakarta. Salah satu ragam tari yang memiliki karakteristik tenang, pelan dengan poros 
atau pusat kekuatan pada cethik.

Ngenceng secara keseluruhan terdiri dari delapan hitungan dengan gerak berkualitas mengalun, tenang, bertumpu pada oyogan dan ngleyek. Ngenceng sebagai motif memiliki kekuatan pada cethik sebagai poros untuk melakukan gerakan ngoyog dan ngleyek. Gerak ngoyog, secara bentuk diawali dengan mendhak lalu cethik sebagai penggerak mendorong perpindahan berat badan dari kanan ke kiri. Sedangkan ngleyek cethik sebagai penggerak mendorong perpindahan berat badan untuk kembali pada posisi semula.

\section{c) Aspek Ruang}

Aspek ruang dalam tari Srimpi Kadang Premati meliputi 2 bagian yaitu ruang imajiner (ruang tubuh penari) dan ruang nyata atau suatu keruangan yang dapat diraba, disentuh, dipakai oleh penari. Kedua bagian aspek ruang tersebut tentunya mempunyai prinsip kebentukan yang berbeda. Artinya, penari dengan tubuhnya menciptakan gerak dengan desaindesainnya, sementara ruang nyata atau area pentas diperlukan sebagai tenpat dimana penari melakukan aktifitas bergeraknya. Aspek ruang imajiner diawali dari ragam ngenceng kemudian melalui proses eksplorasi dan improvisasi menemukan ragam baru seperti sembah semesta, ngenceng tawing, kicat srisig sembah, dan lain-lain. Aspek ruang nyata yang digunakan adalah pendapa. Pendapa secara utuh dapat dilihat dari tiga arah yaitu depan, samping kanan, dan samping kiri. Pendapa sebagai area pentas termasuk jenis rumah joglo simnom (sinom) apitan atau bentuk yang sering disebut rumah joglo trajumas karena rumah joglo bentuk ini memiliki tiga buah pengeret, tiga atau lima buah tumpang, dan empat empyak (atap) emper, (R.Ismunandar.K. 1986:98). Selain itu pendapa memiliki tigasaka yang terdiri dari saka guru, saka rawa, saka emper yang mana keberadaan saka tersebut dapat dipakai untuk mempertegas keempatnya yang masing-masing mempunyai tempat sesuai dengan keblat.

\section{d) Aspek waktu}

Aspek waktu yang digunakan dalam tari Srimpi Kadang Premati dilihat dari pola gerak dan garapannya menggunakan pola waktu kontinyu-berurutan. Pengolahan pola waktu yang terjalin melalui tempo dan ritme sangat bervariasi. Namun pada dasarnya secara keseluruhan dari konsep tari menggunakan pola waktu yang beragam namun tetap kontinyu-berurutan.

\section{e) Variasi}

Variasi merupakan prinsip bentuk yang harus ada dalam sebuah tarian atau koreografi; sebagai karya kreatif harus memahami yang serba "baru". Dalam proses 
pembentukan gerak perlu memperlihatkan nilai-nilai kebaruan itu. Oleh sebab itu selagi ada kesempatan yang baik, dimungkinkan tidak ada putus-putusnya untuk "bervariasi" dari semua aspek yang ada yaitu gerak ruang dan waktu, (Hadi. 2007:26). Pemahaman tentang konsep variasi dilakukan dari semua aspek gerak, ruang dan waktu. Variasi gerak telah dilakukan mulai dari gerak yang sederhana hingga gerak yang memiliki tingkat kesulitan. variasi yang tidak semata-mata hanya pada variasi gerak tetapi juga variasi pada waktu dan ruang. Variasi gerak dapat ditemui pada gerak kicat (gerak berjalan) dilakukan dengan kicat ke depan, ke samping. Dasar dari gerak kicat adalah berjalan ke samping kanan atau kiri dengan tekanan pada angkatan kaki. Variasi gerak kicat ini dilakukan pada saat tangan memegang properti maupun tidak. Penambahan gerak encot setelah kicat, dan penambahan putaran serta leyekan setelah kicat . Pada pola waktu hitungan bervariasi antara hitungan lambat, sedang dan cepat. Dalam hitungan lambat kicat terdiri empat hitungan dalam satu langkah. Dalam hitungan sedang kicat terdiri dari 2 hitungan sedangkan dalam hitungan cepat kicat dapat dilakukan 1 hitungan dua langkah.

\section{f) Repetisi atau Pengulangan}

Repetisi atau pengulangan dilakukan melalui 7 pengulangan dalam konsep Jacqueline Smith (Terj. Ben Suharto. 1985:40) yang meliputi pernyataan kembali, penguatan kembali, gema ulang, rekapitulasi, revisi, mengingat kembali (recal), mengulang kembali (reiterate). Ketujuh pengulangan ini diwujudkan dalam gerak dengan dasar ragam gerak ngenceng. Untuk mewujudkannya tahapan yang dilakukan adalah melakukan eksplorasi dan improvisasi dari gerak tersebut hingga muncul gerak atau ragam baru. Pengulangan ini juga melibatkan aspek ruang, waktu, dan tenaga agar gerak yang terwujud tidak monoton. Misalnya gerak sembah, gerak sembah dilakukan pada level bawah, level sedang dan level atas. Level bawah biasanya dilakukan dengan posisi duduk sila dan jengkeng, untuk posisi sedang dilakukan dengan mendak, sedangan pada level tinggi dilakukan dengan mengabungkan njinjit dengan kicatsrisig.

\section{g) Transisi atau perpindahan}

Transisi dipahami sebagai perpindahan atau sambungan dari gerak yang satu ke gerak yang lain dengan lancar dan terampil, seluruh rangkaian bentuk gerak menjadi lebih efektif menciptakan kesatuan atau keutuhan (Hadi, 2007:27). Dipertegas oleh Jacqueline Smith (terj: Ben Suharto, 1985:73-74) bahwa istilah transisi digunakan untuk menyambung seluruh bagianbagian sehingga secara efektif menciptakan keseluruhan. Transisi ini sangat penting dan barangkali merupakan aspek komposisi yang 
paling sulit. Penata tari bekerja dengan intuisinya, mencari segala kemungkinan celah dan menyelusuri bahwa gerak yang dilakukan terasa enak dan sreg.

Transisi dapat dilakukan bukan dengan gerakan-gerakan besar tetapi juga gerakangerakan kecil. Namun dalam Srimpi Kadang Premati transisi yang digunakan adalah gerak berjalan, berputar, srisig ditempat. Ketiga gerak tersebut sebagai transisi dari ragam gerak selanjutnya sekaligus perubahan formasi agar tarian terlihat lebih aktraktif, menarik, dan menghindari kesan monoton.

\section{h) Rangkaian}

Pemahaman konsep kebentukan tentang rangkaian adalah suatu kontinuitas, adalah salah satu prinsip yang perlu diperhatikan karena bentuk gerak tari dapat dirasakan sebagai satu pengalaman (Hadi, 2007:28). Konsep kebentukan tentang rangkaian lebih mudahnya dipahami dengan bagaimana menyusun atau merangkai gerakgerak tersebut menjadi satu keutuhan tari. Karya tari ini mempunyai lima adegan yang harus divisualkan dengan baik yaitu introduksi, bagian awal, bagian tengah, dan bagian ahkir. Setiap peralihan adegan ditandai dengan perubahan posisi penari, perubahan gerak penari, dan tentunya perubahan iringan tarinya. Rangkaian dari setiap adegan dan rangkaian dari setiap ragamnya disusun sedemikian rupa sehingga menjadi satu kesatuan yang utuh dan dapat dinikmati.

\section{i) Perbandingan}

Dalam kajian teori yang digunakan, tari Srimpi Kadang Premati tidak dapat dijabarkan tentang konsep perbandingannya.

\section{j) Klimaks}

Prinsip klimaks sangat erat hubungannya dalam mempertimbangkan rangkaian yang telah dibicarakan sebelumnya. Susunan atau urut-urutan rangkaian kejadian harus membentuk satu klimaks, agar maksud dari bentuk tari tercapai. Dalam struktur tari ada permulaan, berjalan atau berkembang, dan penyelesaian. Klimaks dinikmati sebagai titik puncak dari perkembangan serta memberi arti dari kehadiran permulaan, perkembangan, dan akhir atau penyelesaian (Hadi, 1996:51).

Tari Srimpi Kadang Premati memiliki lima bagian yang mana dari kelima bagian tersebut terdiri atas permulaan, perkembangan, dan penyelesaian. Permulaan terdiri atas introduksi dan bagian awal. Perkembangan ditandai dengan bagian awal adegan dua dan bagian tengah, dan bagian akhir ditandai dengan pemecahan formasi penari menjadi beberapa fokus untuk menciptakan konflik.

Bentuk gerak yang terdiri dari kesatuan, variasi, repetisi atau pengulangan, transisi, rangkaian, perbandingan, dan 
klimaks, dapat digunakan untuk mengkaji sebuah karya tari. Menganalisis kebentukannya dari setiap aspek yang mengikat yaitu gerak, ruang, dan waktu. Terwujudnya satu sajian tari yang menarik dapat secara utuh dipahami melalui ketujuh prinsip bentuk tersebut. Begitupun dengan tari Srimpi Kadang Premati. Prinsip kebentukan dapat digunakan untuk menganalisa, menjabarkan, menguraikan tarian tersebut secara utuh dan memberikan benang merah yang nyata dari setiap susunan adegan hingga ragam-ragamnya.

\section{Pembelajaran Sejarah dan} Analisis Tari

Pembelajaran Sejarah dan Analisis tari adalah salah satu pembelajaran yang dilaksanakan pada Program Studi Pendidikan Sendratasik, Jurusan Pendidikan Kesenian, Fakultas Keguruan dan IImu Pendidikan di Universitas PGRI Palembang. Pembelajaran tentang pengetahuan sejarah tari dan analisisnya. Pembelajaran Sejarah dan Analisis Tari memberikan bagian-bagian penting dalam menganalisa seni tari dari sejarah, fungsi, bentuk, hingga menelaah seni tari yang berhubungan dengan lingkungan masyarakatnya. Salah satu yang menjadi fokus pembahasan dari pembelajaran tersebut adalah memahami analisis tekstual dan kontekstual. Salah satu yang dibahas dari analisis tersebut adalah analisis tekstual tentang bentuk gerak dengan materi tari Srimpi Kadang Premati. Dipilihnya materi tari ini karena secara wujud atau bentuk tari Srimpi memiliki kompleksitas dalam pembahasannya.

Pembelajaran Sejarah dan Analisis Tari berbobot 2 SKS dilaksanakan pada semester 6 (enam) atau genap, diharapkan dapat memberikan pemahaman terhadap mahasiswa dalam menelaah, menganalisa dari berbagai kajian bidang seni terutama seni tari. Melihat banyaknya teori yang disampaikan maka perlunya mahasiswa untuk mempelajari salah satu kajian teori dan bagaimana menganalisanya. Untuk itu menjadi sangat penting jika dalam proses pembelajaran mahasiswa

diberikan contoh yang lebih kongkrit sehingga nantinya ketika melakukan analisa terhadap suatu bentuk tari tidak lagi merasa kesulitan, tetapi dengan sangat mudah dan lebih berhati-hati dalam mengkaji.

\section{Relevansi Materi Bentuk Gerak Tari Srimpi Kadang Premati Sebagai Materi Pembelajaran Pada Mata Kuliah Sejarah Dan Analisis Tari}

Ketika membahas tentang relevan atau tidaknya suatu materi tari yang akan disajkan sebagai contoh dalam sebuah pembelajaran, maka dapat dilihat dari capaian pembelajarannya. Dalam mata kuliah Sejarah dan Analisis Tari salah 
satunya adalah pembahasan tentang analisis tekstual yang mana capaian pembelajaran yang diharapkan adalah mahasiswa mampu menganalisa tari dalam ruang lingkup tekstual. Dalam beberapa buku teori seni tari yang digunakan sebagai sumber acuan, kajian tekstual terdiri dari beberapa pokok bahasan salah satunya adalah analisis bentuk gerak.

Pemilihan analisis bentuk gerak ini berkaitan dengan menganalisa proses mewujudkan atau mengembangkan suatu bentuk dengan pertimbangan-pertimbangan prinsip-prinsip bentuk menjadi sebuah wujud gerak tari (Hadi. 2007:25). Berdasarkan hal tersebut di atas dapat dipahami bahwa ketika mahasiswa melakukan analisa bentuk gerak akan selalu mengkaitkan tentang proses mewujudkan atau mengembangkan yang dilakukan oleh penata tari atau pencipta tari. Dalam menganalisa bentuk gerak mahasiswa diharapkan dapat melakukan penganalisaan melalui pertimbangan prinsipprinsip bentuk yang terdiri dari kesatuan, variasi, repetisi atau ulangan, transisi atau perpindahan, rangkaian, perbandingan dan klimaks.

Selain hal tersebut di atas, pemilihan materi bentuk gerak berkaitan materi sesudahnya yaitu Analisis Kontekstual serta Pendekatan pada masyarakat dan penulisan data penelitian dalam bentuk laporan. Ketika membahas materi bentuk gerak maka secara sadar mahasiswa akan berpikir kembali dengan materi selanjutnya yang terkait dengan analisis tekstual yaitu analisis kontekstual dan pendekatan pada masyarakatnya. Ketika mahasiswa melakukan analisa tentang Bentuk gerak, maka mahasiswa sebagai peneliti akan berpikir tentang proses yang telah dijalani oleh penata tari. Mahasiswa tidak hanya mencatat apa yang telah dikerjakan oleh penata tari tetapi juga harus mampu mendiskripsikan secara konkret hasil analisisnya.

Tari Srimpi Kadang Premati adalah sebuah karya tari yang memiliki kompleksitas yang dapat dikaji, dianalisa dari sudut kajian bentuk gerak. Tarian tersebut dipilih sebagai materi karena dianggap mampu mewakili tarian lainnya. Banyak pertimbangan yang dilakukan oleh peneliti sekaligus pengajar mata kuliah Sejarah dan Analisis Tari antara lain pertimbangan ide gagasan, pertimbangan jumlah penari, pertimbangan landasan penciptaan, pertimbangan aspek pendukung karya tari, dan lain-lain. Pertimbangan ide/gagasan, tari Srimpi Kadang Premati diawali dengan munculnya suatu gagasan untuk mewujudkan suatu bentuk tari yang didasari dari falsafah Jawa tentang keblat, kadang, sedulur papat kalima pancer. Rangsang awal ini terbentuk atas 
suatu pemikiran bahwa pada dasarnya manusia dalam menjalani kehidupannya disertai oleh saudara yang terwujud dalam bentuk nafsu. Bermula dari rangsang awal tersebut muncul gagasan yang kemudian dituangkan dalam bentuk tari yang memiliki struktur awal, tengah, dan ahkir yang terwujud menjadi lima adegan. Pertimbangan Jumlah Penari. Jumlah penari yang digunakan dalam tarian ini adalah 9 orang penari, dengan pembagian satu penari berkarakter seorang ibu, 3 penari puteri sebagai pembawa sesaji, dan 5 penari puteri yang mewakili sedulur papat kalima pancer. Dari aspek penari inti yaitu lima orang penari puteri, mahasiswa akan mengetahui bahwa menggunakan atau memilih penari tidak dapat secara serta merta tanpa konsep yang jelas. Akan tetapi mahasiswa akan mengetahui bahwa pemilihan penari dilakukan berdasarkan konsep yang jelas, memiliki makna, dan memahami arti penting kedudukan penari. Dalam Srimpi Kadang premati dijelaskan bahwa pemilihan penari dengan beberapa pertimbangan yaitu lima penari sebagai simbol dari keblat papat kalima pancer memiliki kehendak, kekuatan, kemauan yang berbeda-beda dan itu terwujud dalam bentuk gerak, pola lantai, dan aspek pendukung lainnya. Mengacu pada konsep Srimpi dengan penari berjumlah empat orang, dengan pembagian dua di sisi kanan dan dua di sisi kiri atau disebut juga dengan lirang-tangkep. Konsep lirang-tangkep menurut Ben Suharto (1990:64) sebagai simbol Srimpi yang memberi makna tentang keseimbangan dalam segala hal. Pada dasarnya tari Srimpi mempunyai kekuatan, mengandung unsur simbolik yang dalam, dan masyarakat Jawa percaya bahwa tari Srimpi adalah suatu ekspresi antara baik dan jahat, gelap dan terang, atau bumi dan langit. Pertimbangan yang lain adalah kelima penari memberikan kesan asimetri. Satu penari sebagai isi merupakan bagian dari konsep asimetri karena dengan lima penari dapat diolah dalam bentuk alur dan pola lantai yang lebih variatif. Pertimbangan Landasan Penciptaan. Landasan penciptaan yang diacu adalah konsep Srimpi tentang lirangtangkep. Lirang-tangkep diwujudkan dari Srimpi yang empat tetapi dua atau disebut berpasangan, atau dua tetapi satu, Ben Suharto (1990:64). Konsep dua adalah satu ini merupakan konsep dualitas yang tidak dapat diingkari oleh siapa pun. Konsep dasar srimpi adalah suatu bentuk tari yang divisualkan oleh empat penari yang merupakan pengejawantahan dari keseimbangan dunia yang terungkap lewat dualitas yaitu gelap-terang, baik-jahat, langitbumi, laki-perempuan, dan sebagainya. Jika dirangkum maka konsep srimpi adalah 
konsep keseimbangan dan dalam teori bentuk dapat dilihat bahwa konsep keseimbangan dapat terwujud dari simetri dan asimetri dengan pemahaman bahwa simetri memberikan kesan tenang, dan asimetri memberikan kesan mau bergerak, dinamis, dan akan ada perubahan. Konsep keseimbangan tersebut diwujudkan dalam gerak dan pola lantai. Pada konsep keseimbangan gerak yang digunakan adalah ragam ngenceng yang dapat disimpulkan bahwa ragam ngenceng merupakan gerak yang asimetris namun dalam perlakuannya lebih memunculkan kesan seimbang. Hal ini disebabkan karena pada ragam ngenceng melibatkan koordinasi seluruh tubuh dari gerak tangan, kepala, dan perpindahan berat badan secara tepat. Konsep keseimbangan pada pola lantai dibentuk dari lima penari dengan bentuk asimetri dengan pola 1-4, 2-3, 2-1-2. Kehadiran jumlah penari dalam jumlah ganjil atau gasal memberikan kesan pemisahan seseorang untuk menimbulkan konflik, sedangkan penari genap dapat menyatu secara harmonis atau memberikan kesan simetri atau seragam (Smith. Terj. Ben Suharto.1985:49). Pertimbangan aspek-aspek pendukung karya tari. Selain hal-hal yang telah dijabarkan di atas tentunya belum lengkap tanpa aspekaspek pendukung lainnya yaitu tema tari, tipe tari, mode penyajian, tata rias dan busana, area pentas, musik iringan tari, properti tari, properti panggung dan area pentas. Aspek-aspek pendukung karya tari ini merupakan bagian penting yang tidak dapat terpisahkan ketika membahas tentang tekstual dari sebuah karya tari. Semua aspek yang terlibat mewujud menjadi satu kesatuan yang tidak terpisahkan dari bentuk gerak tari.

Berdasarkan penjabaran tersebut di atas maka dapat disimpulkan bahwa materi tari Srimpi Kadang Premati mempunyai relevansi yang cukup baik sebagai materi ajar dan layak dijadikan contoh untuk dipelajari lebih lanjut.

\section{SIMPULAN}

Materi pembelajaran pada mata kuliah Sejarah dan Analisis Tari mencakup beberapa materi antara lain Periodesasi Tari menurut jamannya, Fungsi tari dan Bentuk tari, Menelaah hubungan seni tari dengan seni lain atau bidang keilmuan yang lain, Analisis Tekstual dan Kontekstual, Pendekatan pada masyarakat dan penulisan data penelitian dalam bentuk laporan. Dari sekian banyak materi dipilih materi yang memiliki tingkat kesulitan yang cukup tinggi bagi kalangan mahasiswa yaitu analisis tekstual. Analisis tekstual mencakup banyak analisis salah satunya adalah bentuk gerak. Pemilihan materi bentuk gerak tari Srimpi Kadang Premati sebagai materi 
pembelajaran pada mata kuliah Sejarah dan Analisis tari sangatlah tepat. Materi bentuk gerak dari tari Srimpi Kadang Premati tersebut memiliki kompleksitas yang cukup baik dan rumit, namun demikian pada dasarnya mahasiswa cukup dapat memahami dari materi tersebut.

\section{DAFTAR PUSTAKA}

Hadi, Y. Sumandiyo, 1996. Aspek-aspek Dasar Koreografi Kelompok. Yogyakarta: Manthili. 2007. Kajian Tari Teks dan Konteks. Yogyakarta: Pustaka Book Publisher. Ismunandar K, R. 1986. Joglo: Arsitektur Rumah Tradisional Jawa. Semarang: Dahara Prise.

Prawiroatmodjo,S. 1980. Bausastra Jawa—Indonesia, Jakarta: Gunung Agung.

Smith. Jacqueline, Terj: Ben Suharto. 1985. Komposisi Tari: Sebuah Petunjuk Praktis Bagi Guru, Yogyakarta: Ikalasti.

Sudarsono,dkk, 1978. "Kamus Istilah Tari dan Karawitan Jawa", Jakarta: Penelitian Bahasa dan Sastra Indonesia dan Daerah.

Suharto, Benedictus. 1990. "Dance Power: The Concept of Mataya in Yogyakarta Dance", Los Angeles: University Of California. 